\title{
JUTE FIBER-REINFORCED POLYMER COMPOSITES: A COMPREHENSIVE REVIEW
}

\section{S RABBI, TANSIRUL ISLAM \& M M K BHUIYA}

Department of Mechanical Engineering, Chittagong University of Engineering \& Technology (CUET), Chattogram-4349, Bangladesh

\begin{abstract}
Researchers and scientists, nowadays, are trying to explore the eco-friendlier materials which would significantly reduce the dependency on synthetic fibers and its composites. Jute fiber could be a suitable substitution to synthetic fiber as a reinforcement of polymer. The more enhancements of the mechanical properties can be achieved utilizing several fiberreinforced parameters which include fiber content, fiber loading, size, and orientation, etc. Moreover, the properties of composite materials can be enhanced using the perfect matrix combination which includes polypropylene, polyester, epoxy resin, etc. Furthermore, chemical treatments of the fiber can improve the properties of jute fiber composites. This paper discusses a comprehensive review of all the factors include fiber parameters, chemical treatments of fiber, and manufacturing processes of composites that affect the mechanical properties of the jute fiber-reinforced polymer composites.

KEYWORDS: Jute Fiber, Polymer, Chemical Treatment, Manufacturing, Mechanical Properties
\end{abstract}

Received: May 26, 2020; Accepted: Jun 16, 2020; Published: Jun 30, 2020; Paper Id.: IJMPERDJUN2020290

\section{INTRODUCTION}

Nowadays people are more driven towards the usage of materials that are made from natural fibers since they are considered as one of the most eco-friendly materials, additionally they can be a viable substitution for synthetic fiber [1]. Natural fibers possess some excellent properties, such as they are renewable, biodegradable, non-abrasive, low cost and lower density, which led to growing interests of using these natural fibers as a reinforcing agent [2].Advancement of composite materials and their manufacturing methodology may be a standout amongst those practically noteworthy achievements in the history of materials. Composite materials would be created from claiming two alternately additional physically as well as synthetically different phases, consolidated to process a mass property which would unique in relation to the individuals from claiming its constituents. Composites hint at preferred impact strength, tensile strength, also flexural quality similarly as contrasted with customary materials [3].Between two materials, the stronger one will be known as reinforcement and the lighter material is known as matrix. Reinforcement in the composite enhances hydrophobicity, durability, wet ability, firmness of the composites and also improves various strength like tensile strength, compressive strength, impact strength, flexural strength and so on [4].An extensive variety of natural fibers built polymer composite materials need been created utilizing changed manufactured strategies with augmenting its requisition starting with automotive to biomedical fields [5]. Natural fibers are fibers that are evaluated from various plants and living species. Different kinds of available natural fibers are shown in Figure 1.And these fibers are continuously being applied for reinforcement in the polymer framework on supplements those sure particular properties in the final products [5, 6].Different types of substances (lignin, hemicelluloses etc.) that partly secure the natural fiber surfaces restrict the $\mathrm{OH}$ groups of the 
fibers to react with polymer matrix [8,9]. The effectiveness of natural fiber composites rely on several factors but mostly the contaminants exhibit on fiber surface [10]. Chemical treatments are proved as the good solution which substantially increases the phase adhesion between the fiber and matrix which results in improved properties of the composites [11, 12].Researchers are being attracted to concentrate on enhancing the phase adhesion of the jute fiber and various polymer matrixes like epoxy, polypropylene, polyester and polylactic acid since the scope of utilizing jute fiber is ceaselessly soaring. Jute has some excellent features which include stiff, hydrophobic, dampness absorption etc. which make it more suitable for composite than other agro-fibers [13-15]. Additionally, low cost and non-abrasiveness of jute fiber make the composite manufacturing process more cost-effective [16]. Jute fiber reinforced composite has a great value in German automobile door-panel industry [17].

This paper gives a thorough review of the past studies now accessible directing, including the issues for enthusiasm. The paper is organized as follows. Section 2 is discussed the chemical treatments of jute fiber before compounding with matrix. Different composite manufacturing processes are briefly explained in Section 3. Types of the matrix are presented in Section 4. Section 5 is unfolded the mechanical properties of jute fiber-reinforced composites and its affecting factors. Conclusions are drawn and future research options are recommended in Section 6.

\section{CHEMICAL TREATMENT OF JUTE FIBER}

Jute fiber has hydrophilic nature whereas the polymer matrix has hydrophobic nature, and these two are incompatible with each other. The hydrophilic jute fibers offer poor resistant to moisture resulting in high water absorption, consequently, the jute fiber composites exhibit poor tensile properties. Moreover, the adhesion of the matrix with jute fibers becomes poor due to the non-cellulosic substances like lignin and hemicelluloses which structure the cells of jute [18]. The OH groups of these substances also let the macromolecules to form hydrogen bonds between them throughout the fiber [19]. When the fibers subjected to humidity, these hydrogen bonds break and form new ones with the water molecules which further induce swelling (Figure 2). Turko et al. claimed that the calculated value is double of the actual swelling pressure [20].The hydrophilic characteristics of jute fiber can be reduced to enhance the mechanical properties using chemical treatment [2125]. Another thing is that each elementary fiber of jute has a hollow channel which created additional porosity when use as a reinforcement [26]. Those surface modification techniques penetrate into those pores by creating a mechanical coating. There are a significant number of surface treatment processes which had been experimented on natural fibers; nevertheless, very few had been applied on jute fibers, discussed as follows:

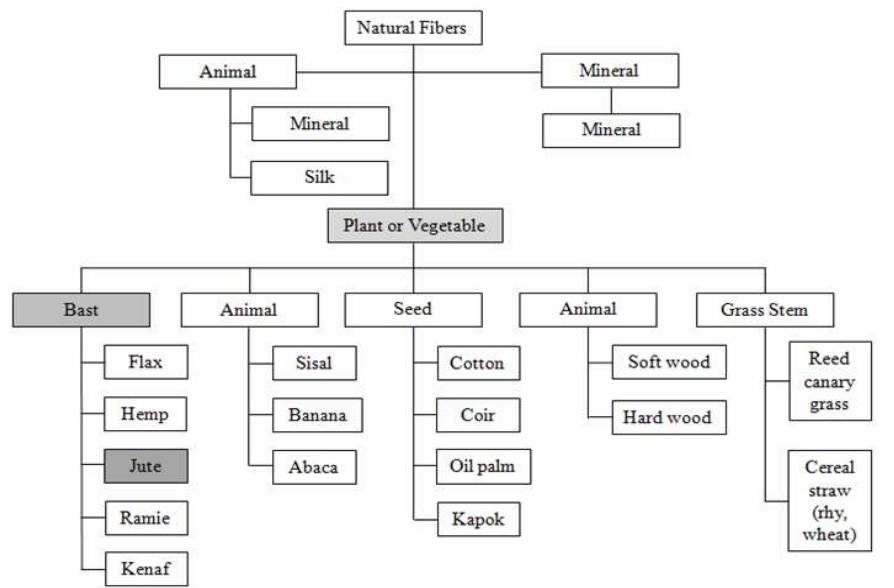

Figure 1: Different Kinds of Natural Fibers (Adapted from [7]). 


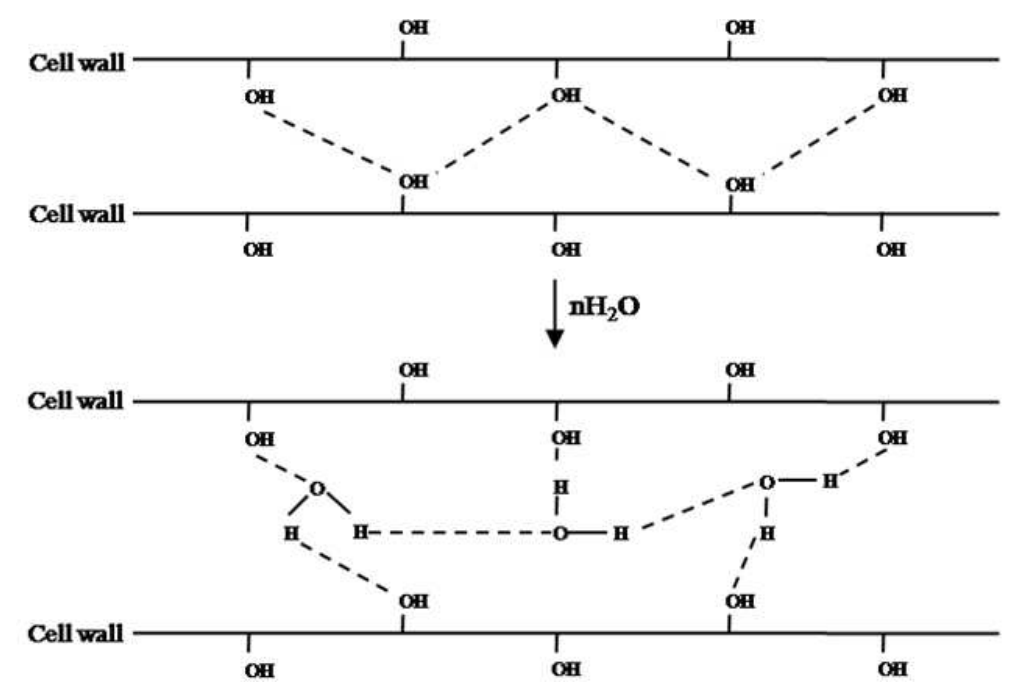

Figure 2: Formation of Hydrogen Bonds between the OH Groups of Molecules (Adapted from [19]).

\section{Alkaline Treatment}

One of the basic surface treatment processes of natural fibers is alkaline treatment. The main chemical used for this purpose is Sodium hydroxide. Generally, $\mathrm{NaOH}$ changes the innate cellulose structure by a process known as alkalization $[27,28]$. Alkalization process de-polymerizes the molecular structure of the parent cellulose by producing short length crystallites. Zeronian provided the best definition of alkalization [29]. Cellulose is called alkalized cellulose when it is subjected to an alkali metal hydroxide solution which converts its structure to cellulose I to II. The $\mathrm{NaOH}$ and $\mathrm{OH}$ group of cellulose react in a way that the $\mathrm{OH}^{-}$of $\mathrm{NaOH}$ reacts with the $\mathrm{H}^{+}$of cellulose $(\mathrm{Cell}-\mathrm{OH})$ and produce water. The $\mathrm{H}^{+}$of cellulose $(\mathrm{Cell}-\mathrm{OH})$ basically replaced with $\mathrm{Na}^{+}$and converts to Cell-O-Na ${ }^{+}$. The impurities of the surface become residue of the reaction. Ray et al. followed the alkalization process in a way that first the chopped jute fiber was soaked into a solution of aqueous $\mathrm{NaOH}(5 \mathrm{wt} \%)$ at $30^{\circ} \mathrm{C}$, and they were soaked into the solution for different periods [30]. When the period is over, $\mathrm{NaOH}$ from the surface of the fiber was removed by washing the soaked fibers several times. Then dilute acetic acid was used to neutralize it and also washed with water. The fibers were dried for 48 hours at room temperature after ensuring the $\mathrm{pH}$ level 7. The fibers were then oven-dried for another 6 hours at $100^{\circ} \mathrm{C}$. A similar process of alkalization had been followed by Leonard et al. [31] and Manikandanet al. [32] but they additionally calculated the weight loss of fiber due to this alkaline treatment [33]. Bruno et al. produced alkalized fiber by following some steps [34]. First, the fibers and acetic acid solution were prepared and heated at $75^{\circ} \mathrm{C}$ for 1 hour with continuous stirring. Then the aqueous solution of $\mathrm{NaOH}(6 \mathrm{wt} \%)$ was added to the previous solution at $80^{\circ} \mathrm{Cwith}$ continuous stirring for another 1 hour. Finally, they were soaked in distilled water until complete purification. A different method had been approached by Anna Dilfi et al. who first removed the dirt or impurities from the fiber surface by washing them for 3 hours in an ultrasonication bath $\left(80 \mathrm{~W}, 20^{\circ} \mathrm{C}\right)$ with pure water [35]. Then, the fibers were oven-dried at $60^{\circ} \mathrm{Cfor}$ almost 24 hours. After that, the dried fibers were again ultrasonicated $\left(80 \mathrm{~W}, 20^{\circ} \mathrm{C}\right)$ with a solution of aqueous $\mathrm{NaOH}(1 \mathrm{wt} \%)$ for 1 hour. Then they were cleaned and dried like before. Atkins reported that cellulose I totally convert into cellulose II only when tension is not applied during an alkalization process, otherwise the conversion occurs partially [36]. Mishra et al. [37] concluded that alkalization improves the phase adhesion by making the surface rougher and increasing the exposed cellulose amount of the fiber surface [38]. It also increases strength compatibility along the fiber length, which further increase in strength at the enervated point in fiber $[39,28]$. It is evident that the mechanical properties of fiber-reinforced composite like impact strength, fatigue, 
compressive strength, flexural strength and dynamic behaviors of fiber-reinforced composite can be enhanced by alkaline treatment [40-42].However, an interesting fact had been discovered by Murkhejee et al. regarding alkaline treatment that the mechanical properties of composite become poorer if $\mathrm{NaOH}$ is used more than $1 \%$ as it weakens the fibers [43].Jute fibers were treated with $1 \%$ and $18 \% \mathrm{NaOH}$ solution in their experiment.

\section{Silane Treatment}

A Silane treatment is another most important chemical treatment method after alkaline treatment that is used widely for modifying fiber surfaces. It is a multifunctional molecule with chemical formula $\mathrm{SiH}_{4}$. This coupling agents increase the adhesion between fibers and polymer matrix, consequently the stability of the composite material upgrade. It may reduce the amount of cellulose hydroxyl groups from the interface of fiber-matrix. A siloxane bridge connects the fiber surface and matrix chemically. In this treatment process of the fiber, miscellaneous stages of reaction for instance hydrolysis, condensation and bond formation occur [44]. Silanol has two ends; one end makes a reaction with cellulosic $\mathrm{OH}$ groups while others get reacted with matrix during the condensation process. Uniformity is provided across the interface of the composite due to this co-reactivity. It further refrains the swelling of fibers into the matrix [45, 46], as a result, fiber gets more adhere to the matrix [22].There are some micro-pores on the surface of natural fibers which are filled by silane agent as it builds a coating on the surface which is mechanically interlocked. Valadez-Gonzalez compared silane treated fiber with alkaline treated fiber and reported that alkalized fiber composite was much weaker than silane treated fiber composite [38]. Agarwal et al. provided the reaction scheme of silane as follows [47]:

$$
\begin{aligned}
& \mathrm{CH}_{2}=\mathrm{CH}-\mathrm{Si}\left(\mathrm{OC}_{2} \mathrm{H}_{5}\right)_{3} \stackrel{\stackrel{\mathrm{H}_{2}}{\longrightarrow}}{\longrightarrow} \mathrm{CH}_{2}=\mathrm{CH}-\mathrm{Si}(\mathrm{OH})_{3}+3 \mathrm{C}_{2} \mathrm{H}_{5} \mathrm{OH} \\
& \mathrm{CH}_{2}=\mathrm{CH}-\mathrm{Si}(\mathrm{OH})_{3}+\text { Fiber-OH } \rightarrow \mathrm{CH}_{2}=\mathrm{CH}-\mathrm{Si}(\mathrm{OH})_{2} \text {-O-Fiber }+\mathrm{H}_{2} \mathrm{O}
\end{aligned}
$$

Sever et al. used c-Methacryloxy-propyl-trimethoxy-silane for the silane treatment of jute fibers polyester composites [48]. Three different concentrations $(0.1 \%, 0.2 \%$, and $0.3 \%)$ of silane were used in their study and the silanized fibers were compared with the untreated jute fiber composites. The best result was found when $0.3 \%$ concentrated silane was applied and the mechanical properties of silanized fiber composite were significantly higher than the untreated ones. Seki treated the jute fibers on the solution of oligomericsiloxane (1 wt $\%$ ) and alcohol (96 wt \%) for 1hour [49]. He then compared the change of jute-polyester and jute-epoxy composite's properties. His experimental results reported that alkalized jute-epoxy composites showed around $12 \%$ lower strength than silanized jute-epoxy composites. In the case of jute polyester composite, it was $20 \%$ higher. Bruno et al. prepared the silanized fiber in the same manner that was followed to prepare alkalized fiber except methanol was used to make the solution [50]. It was prepared with $0.12 \mathrm{~g}$ of 3aminopropyl-trimethoxysilane in $5 \mathrm{ml}$ of methanol. The solution was added drop wise to the fiber suspension. It was kept for $1 \mathrm{~h}$ at room temperature and extra $20 \mathrm{~min}$ at $60^{\circ} \mathrm{C}$ [51]. Then the fiber was washed and dried as before.Again, a different method had been approached by Anna Dilfi et al. who ultrasonicated the pretreated fibers with a solution containing $1 \%$ silane coupling agent for 1 hour in a mixture of ethanol and water where the ratio of the ethanol and water was maintained as 60:40 [35]. After that, the fibers got washed and oven-dried for 24 hours at $60^{\circ} \mathrm{C}$. They also investigated the accumulation of alkali and silane treatment together on the surface of jute fibers. First, an aqueous solution of $\mathrm{NaOH}$ ( 1 wt $\%$ ) was used to treat the fibers and then the alkalized fibers had been treated with silane coupling agent (1 wt \%) solution. This combination showed improvement in mechanical characteristics better than individual treatment. 


\section{Acetylation}

An organic compound containing an acetyl functional group participates in a reaction; it can be described as acetylation. The acetylation of natural fibers is mainly an esterification method by which the cellulosic fibers are plasticized. In this modification process, acetyl groups substitute the cellulosic $\mathrm{OH}^{-}$groups of the fiber surface, which results in enhancement of the properties of the composite. Consequently, it increases the hydrophobic nature of the fiber and dimensional stability as well [44].Abdul Khalil et al. described the reaction as follows [51]:

Fiber- $\mathrm{OH}+\mathrm{CH}_{3} \mathrm{COOH}-\mathrm{OCOCH} \mathrm{H}_{3} \rightarrow$ Fiber-OCOCH${ }_{3}+\mathrm{CH}_{3} \mathrm{COOH}$

Moreover, the fiber gets more interlocked with the matrix through this treatment process as it provides with less number of void contents [52, 22].To accelerate the reaction, first the fibers are immersed into a solution of acetic acid. After that, the soaked fibers are again immersed into an acetic anhydride solution with higher temperature for several hours [53]. Rowell and Young treated several natural fibers with acetic anhydride and analyzed the effects of moisture content [54]. Results showed that the resistivity to moisture can be improved by this treatment. The investigation of Sahoo et al. indicated that acetylated jute shows more hydrophobicity, dimensional stability, and resistant to fungal attack than the unmodified jute [55].

\section{Acrylation and Acrylonitrile Grafting}

Acrylic acid $\left(\mathrm{CH}_{2}=\mathrm{CH} \equiv \mathrm{COOH}\right)$ is one of the most used coupling agents to ameliorate the fiber-matrix bonding. The cellulosic $\mathrm{OH}$ groups of the fiber get removed by this agent. Radicals are usually generated together with chain scission by treating cellulose with high energy radiation [56]. The reaction between the cellulosic $\mathrm{OH}$ groups and acrylic acid is initiated by these free radicals. It forms a link among the cellulosic $\mathrm{OH}$ groups; as a result, the $\mathrm{OH}$ groups that are responsible for fibers' hydrophilic characteristics get reduced. Thus, the hindrance to moisture gets increased. Acrylation uplifts the capacity of stress transferring at the fiber-matrix interface; consequently, the properties of the composites get enhanced [57-59]. In this process, alkali pretreated fibers get soaked in the solution that contains acrylic acid of different concentrations at higher temperatures for a while, then it was washed through an aqueous-alcoholic solution and ovendried [57]. Another effective method of surface modification can be applied on the fiber surface which is called grafting and usually done by acrylonitrile $\left(\mathrm{CH}_{2}=\mathrm{CH} \equiv \mathrm{A}-\mathrm{C} \equiv \mathrm{N}\right)$. Here, free radicals are initiated by acrylonitrile, the reaction occurred by dehydrogenation and oxidation process. Mohanty et al. provided reaction of AN with fiber hydroxyl group as follows [60]:

Fiber- $\mathrm{OH}+\mathrm{CH}_{2}=\mathrm{CH} \equiv \mathrm{A}-\mathrm{C} \equiv \mathrm{N} \rightarrow$ Fiber- $\mathrm{O}-\mathrm{CH}_{2}-\mathrm{CH}_{2}-\mathrm{C} \equiv \mathrm{N}$

Patel et al. used both alkaline treatment and acrylation as the surface modification of jute fiber epoxy-phenolic composite [61]. First, the jute fibers were alkalized with an aqueous solution of $\mathrm{NaOH}(1 \mathrm{wt} \%)$ and then acrylation applied on the alkali pre-treated fiber.

\section{Maleated Coupling Agents}

In this process, the maleated coupling agents also act as a reinforcement of the composite [62-65]. This chemical treatment method shows some unique advantages in a way that it not only modifies the surface of the fibers but also the matrix to ensure improved interfacial adhesion, consequently, the composite properties enhanced [66-68].This method is best applied when the matrix is polypropylene because the reaction between the polypropylene chain and maleic anhydride makes the 
maleic anhydride cohesive. As a result, MAPP (maleic anhydride grafted polypropylene) is produced and acts as an agent to reinforce the composite. The $\mathrm{OH}$ groups of cellulose are removed by maleic anhydride, a carbon-carbon bond is formed with the matrix and hence hydrophilic tendency of the fiber get reduced [69]. This covalent bond forms a linkage bridge which connects the fiber and matrix, and eventually, better mechanical interlocking and wet ability can be achieved between them [70]. Mohanty et al. applied this process for the modification of jute fiber reinforced polypropylene composites [60]. In their process, the fibers were soaked in MAPP solution at $100^{\circ} \mathrm{C}$ in toluene. Three different concentrations of MAPP $(0.3 \%, 0.5 \%$ and $1 \%)$ applied on the fiber surface and they observed their effect for three different periods ( 3,5 and 10 minutes). MAPP with $0.5 \mathrm{wt} \%$ concentration showed the best result. Various mechanical properties had been observed to be improved by this treatment.

\section{Miscellaneous Treatment}

Various chemicals, such as Oleoyl chloride, dichloromethane, pyridine etc. are considered as fatty acid derivate. Basically, these react with the $\mathrm{OH}$ groups of cellulose fiber and modify the fiber surface. The reaction between the fatty acid derivative and $\mathrm{OH}$ groups of cellulose fiber is known as etherification, during which the molecules penetrate into the fiber structure, improve wetting as well as hydrophobicity. Corrales et al. used dichloromethane and pyridine solvent to modify jute fibers [71]. The whole treatment process was performed under a dry nitrogen atmosphere. JiríMilitký and Jabbar introduced some different surface modification techniques, for example, ozone treatment, laser treatment, enzyme treatment, plasma treatment on the jute fiber surface [72]. The enzyme treatment was done by dipping the jute fiber into a solution for $2 \mathrm{~h}$ at $50^{\circ} \mathrm{C}$, and the liquor ratio was maintained as 10:1. The solution was prepared by dissolving some antifoaming agent into distilled water. After soaking the fiber into that solution, distilled water was used to wash it and then kept to dry at room temperature. An ozone generator was used in the ozone treatment process which continuously generates ozone gas from oxygen. The ozone generator supplies the ozone gas to a closed container. The jute fibers were kept in that container for 1 hour. To perform laser treatment, a commercial carbon dioxide pulse infrared laser was used which generates a laser beam. The laser power was $100 \mathrm{~W}$ in their study. The jute fibers interact with the laser by material evaporation, surface roughness variation or thermal decomposition [73]. Jute fibers were treated with for 60s with DBD (dielectric barrier discharge) plasma in the plasma treatment process. In their study, the discharge power and pressure were 190W and 1 atmospheric pressure, respectively.

\section{COMPOSITE FABRICATION PROCESS}

Composite fabrication is one of the most important factors that affect the mechanical and dynamic properties of natural fiber composites. The processing technique depends on various parameters like length of fiber, their orientation, the type of fiber whether they are short, unidirectional or bidirectional, woven or non-woven etc. To fabricate the composite, various methods which include vacuum-assisted resin transfer molding (VARTM), hand layup, injection molding and pultrusion are followed etc $[74,75]$.The manufacturing process that had been used to fabricate jute fiber composite is being discussed in the following subsections.

\section{Hand Lay-up Technique}

The hand lay-up method is one of the most conventional methods where each ply is handled only by hand and is stacked layer-by-layer up to the desired thickness. JiríMilitký and Jabbar used hand layup technique to fabricate the composite which is composed of jute fabric and resin [72]. They used a hand roller to mix the jute fabric with resin, and the 
composite laminate consisted of 3 layers of jute fabric in the same direction. The same procedure was applied by a lot of researchers. Mohammad Neaz Morshed et al. [76], Seki [48], Saha et al. [77], M. R. Sanjay and B. Yogesha [78], Vijay Chaudhary et al. [79], Siva Bhaskara et al. [80] and several researchers used this hand layup method to fabricate jute fiber composite. Their processing technique was more or less the same but some introduced one or two new formulas to make the techniques more effective. Mohammad Neaz Morshed et al. used a tailor-made mold to produce the desired size of the composites [76]. Saha et al. placed myler film on each side of the stack to release the composite laminates easily and ensure a uniform surface finish [77]. A spray gel was used to release the laminates. Vijay Chaudhary et al. utilized the hand layup method to develop bio-composites [79]. R.A. Braga and Magalhaes Jr. followed some steps to fabricate jute fiber reinforced epoxy composites [81]. A diamond cutter was used to size the composite properly. Siva Bhaskara et al. fabricated jute fiber-reinforced composite slabs by two approaches [80].

\section{Injection Molding Process}

Injection molding is a manufacturing process for producing parts by injecting molten material into a mold. Anup Kumar Ghosh used a twin-screw extruder for compounding jute fiber and polylactic acid [82]. The compounded jute fiber and polylactic acid then pressed into a micro injection molding machine for fabricating the desired bio-composites. Patel et al. used two different kinds of epoxy to fabricate the composite [61]. Epoxy resin of bisphenol-C (EBC) [83] and bisphenolC-formaldehyde (BCF) [84]resins were used as the polymer matrix. Jute, EBC and BCF then pressed between two preheated roller mills under high pressure and high temperature to be mixed with together uniformly [85]. The half of the total volume of composite had been occupied by jute and the other half volume had been occupied by EBC and BCF equally. Li Yan et al. maintained some different approaches to make the composite with the best properties [86]. The sheet was protected by tacky tape to resist air flow, vacuum desiccators was used for removing voids, finally, pinette press (hot press) was used to make composite having desired thickness. Mixer-injection molding was used by A. K. Bledzki et al.to fabricate the jute fiber polypropylene composites [87]. The fiber and matrix are mixed by high-speed cascade mixer. Mahbub Hasan et al. made an improvement of physio-mechanical properties of jute fiber reinforced polypropylene by post-treatment [88, 89]. The composites were manufactured by injection molding. Initially, the jute and polypropylene were extruded in a single screw extruder. After that, the extrudates were ground in a grinding machine prior to injection molding. Yuqiu Yang et al. observed the impact of jute fiber contents and hot water immersion on jute/polypropylene composites' tensile properties [90]. They were extruded and dry blended before injection molding.

\section{VARI, Pultrusion and Others}

Anna Dilfi et al. used the VARI process to fabricate jute fiber epoxy composites which are illustrated in Figure 6 [35]. The jute fibers were placed into a glass mold unidirectionally. The epoxy resin was injected into the jute fibers under vacuum pressure. A different approach had been adopted by Sarkar et al.to fabricate jute fiber reinforced vinylester composite [40]. A hollow cylinder glass tube was used as a mold and the mixture of jute fiber and vinylester was pultruded through that tube. S. Mohanty and S. K. Nayak first removed all the impurities of jute fibers which were chopped into short length [60]. A two roll mill machine had been used for mixing the fibers with polypropylene, and then the composite sheets were prepared by a compression molding process. Hazizan et al. prepared the jute fiber reinforced polyester composites by a thermo set pultrusion machine [92]. The jute fibers were mixed with unsaturated polyester by a resin impregnation tank. The mixture was then pulled by a pulling device into a die to produce the desired shape of the composite. The production speed and the die stock are determined by that pulling device [90]. 


\section{MATRIX COMBINATION}

Polymers are considered as one of the most used matrices as they have some excellent quality like they can be easily processed at low temperature, light-weight and both kinds of polymer (thermoplastic and thermo set) are suitable as matrices with natural fibers [91]. Matrix determination will be constrained by the temperature toward which natural fibers corrupt. Maximum numbers of natural fiber composites are not thermally stable above $200^{\circ} \mathrm{C}$, in spite of the fact that under the exact condition it is possible that they can be processed at a higher temperature for short period [92]. Not all the thermoplastics can be used as matrix due to this limitation. Thermoplastics, for example, polypropylene, polystyrene, polyester, polyethylene, polyolefin etc. which can be mollified beneath the above-mentioned temperature, can be used as a matrix [93]. Although lot of thermoplastic polymers are available to be used as a matrix, among them polyethylene and polypropylene are mostly adopted with jute fiber [94-97]. As far as thermo set is a concern, the polymer that mostly used as a matrix is unsaturated polyester [98-100], epoxy resin [101-106], phenol-formaldehyde [109]etc. Studies have shown that polylactic acid shows better mechanical properties than polypropylene [105].Gopinathet al. conducted a comparative analysis to find out the best matrix combination with jute fiber [106]. Experimental result suggests that the jute-epoxy combination show better tensile strength whereas jute-polyester combination indicates better flexural strength and depicted in Figure. 3. Investigation showed that jute-polyester required considerably less manufacturing time than jute-epoxy combination. Lifangliu studied the biodegradability of jute fiber where Poly-Butylene-Succinate (PBS) was used as matrix. Different concentrations of PBS along with the weight percentage of jute were used in the study [107]. It was found that jute fiber with 10\% PBS losses 62.5\% weight after 180 days (Figure 4).Numerous researchers observed the scanning electron microscopy (SEM) of jute fiber-reinforced composite. Mohanty et al. observed the SEM micrograph of jute/PP composites [60], while Tripathy et al. observed the same of jute/epoxy composite [108]. The SEM photographs are depicted in Figure 5.
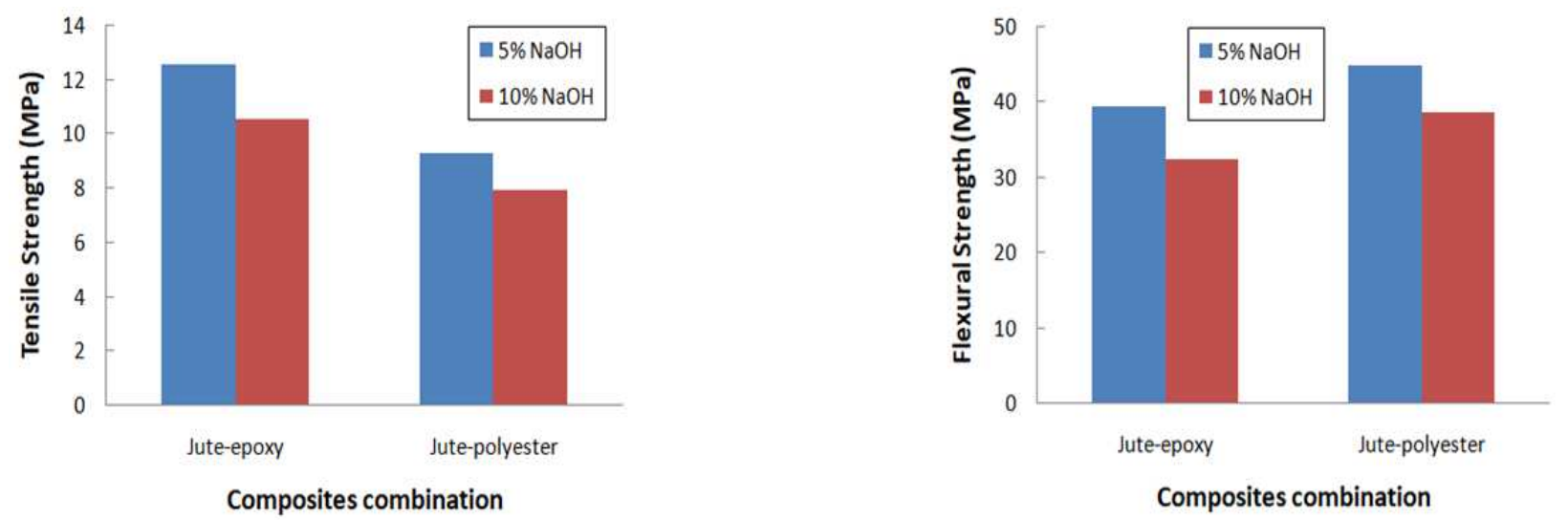

Figure 3: (Left) Tensile Strength, and (Right) Flexural Strength Variation for 5\% and 10\% NaOH Treated Jute Reinforced Epoxy and Polyester Composites (Adapted from [106]). 


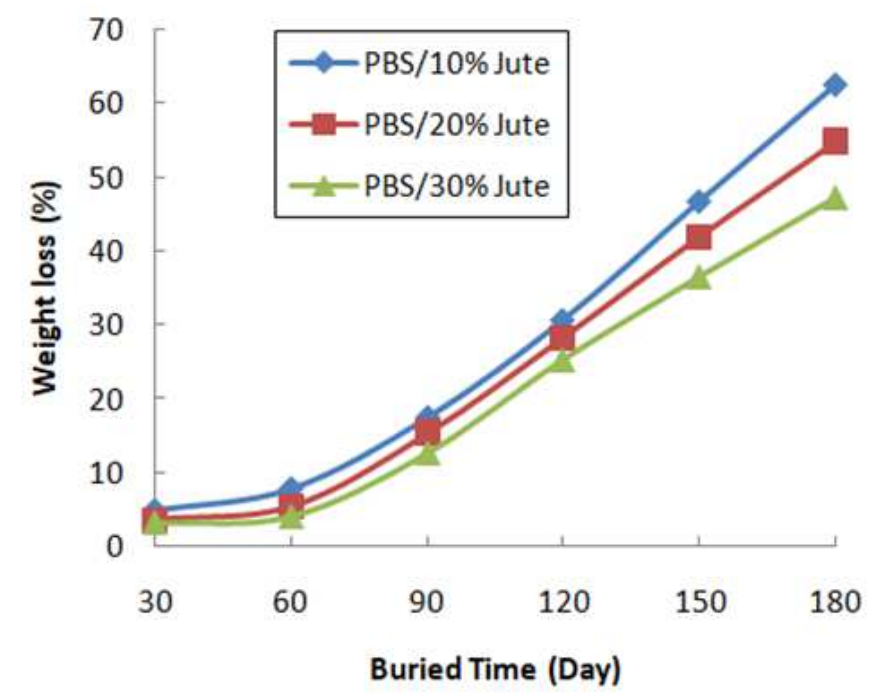

Figure 4: Weight Loss of Buries Specimens with Different Fiber Contents (Adapted from [107]).
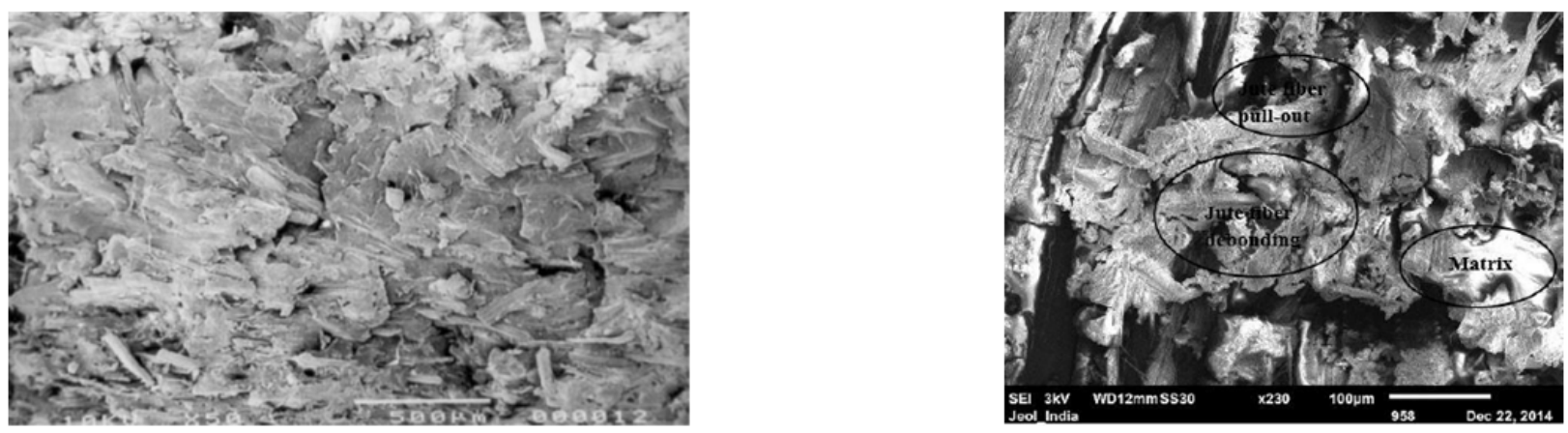

Figure 5: SEM Micrograph of (Left) JF/PP, and (Right) JF/Epoxy Composites (Adapted from [60, 109]).

\section{MECHANICAL PROPERTIES}

A number of factors affect the mechanical properties (Tensile strength, Flexural strength, Impact strength) of fiberreinforced composite, such as types of surface modification methods, composite fabrication techniques, matrix combination and so on [110]. Generally, higher strength and stiffness are possible for those higher execution plant fibers over the promptly accessible animal fibers [111, 112]. It has been provided that the higher fiber contents increase stiffness but fiber contents are limited up to 55-65 $\mathrm{m} \%$ [113-116]. Berhanuet al. found that the increase of jute fiber content in the composite can improve the mechanical properties of the composite but the weight percentage of jute fiber should not exceed $40 \%$ [117]. Figure 6illustrates that the tensile strength reduced after $40 \%$ of the fiber loading though the tensile modulus increases with weight percentage of the jute fiber. Long discontinuous jute-reinforced PP composites fabricated by carding and hot-pressing process with fiber weight fraction varying from $10 \%$ to $70 \%$ in steps of $10 \%$ were studied [118]. Experimental results illustrated that the tensile and modulus strength of the composites increased with increasing fiber loading and a maximum was reached before falling back at higher weight fraction. These were illustrated in Figure 7. Priyadarshini Tapas et al. had observed the outcome of adding filler to composite. In their experiment, epoxy was selected as a matrix whereas $\mathrm{Al}_{2} \mathrm{O}_{3}$ (Filler) and jute fiber were selected as reinforcement [119]. Figure 8 depicts that the $10 \mathrm{wt} \%$ of $\mathrm{Al}_{2} \mathrm{O}_{3}$ exhibits maximum tensile and flexural strength at $30 \%$ of the jute fiber loading. Dash et al. claimed that the types of fiber are greatly responsible for the compressive and tensile properties of composites [120]. They concluded that jute fiber composite has higher compressive strength than bamboo fiber composite but tensile strength is lower than the later. 
Zamriet al. had used distilled water, sea water and acidic water in their study and the jute fiber polyester composite was immersed into those individually to test the water absorption of the composite [121]. The results are showed in Figure 9.Gujjalaet al. used different number layers in the hand layup process with glass and jute fiber [122]. Four different sequences have been fabricated and their properties have been evaluated (Figure. 10).

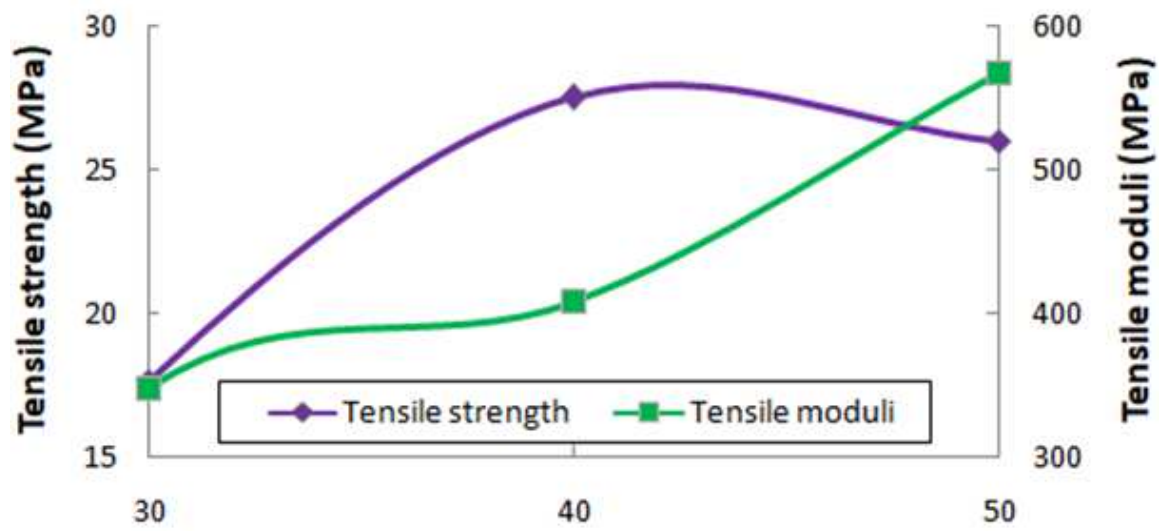

Fiber loading (Wt \%)

Figure 6: Effect of Jute Fiber Wt \% on (Left) Tensile Strength, and (Right) Tensile Moduli of JF/PP Composites (Adapted from [117]).

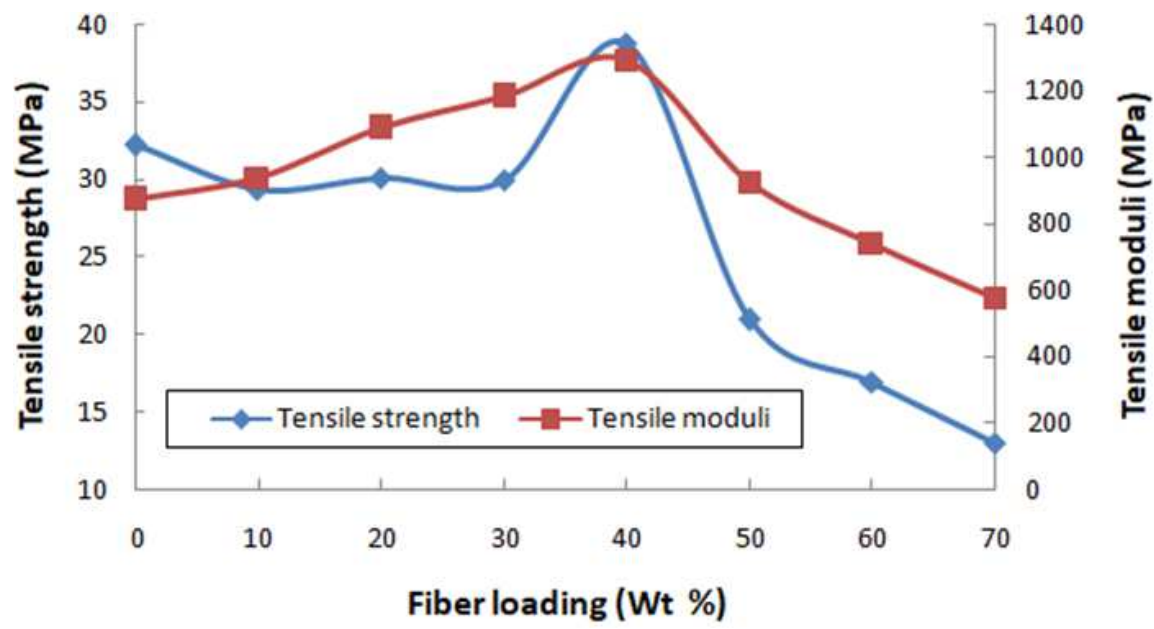

Figure 7: (Left) Tensile Strength and (Right) Tensile Moduli of Bio-Composites of PP vs. LongDiscontinuous Jute Fiber Weight Fraction (Adapted from [118]).

Pujari et al. examined the potential of jute fiber composites and compared it with banana fiber composite [123].M. Ramesh et al. studies the accumulation of fibers, where accumulated jute and glass fiber composite showed highest tensile strength, whereas the mixture of jute and sisal fiber had higher impact and flexural strength (Figure. 11) [124].Araoet al. established a process to enhance the overall strength of jute fiber reinforced polylactic acid composites [125]. It was claimed that the suppression of hydrolysis is required to ameliorate various mechanical properties of the composite. Hind Abdellaouiet al. had used a variation of hybrid sequences to observe how hybridization affects the mechanical properties of the composite [126]. They proposed a mathematical modeling to predict the mechanical characteristics for various directions of jute fiber composites with different stacking sequences (Figure. 12). A comparative study had been performed by Bledzki et al. where JF/PP composite was compared with flax and abaca fiber [127]. Jute fiber composite showed better tensile strength than the others; however, abaca fiber showed the highest flexural strength. It has been found by M. A. Mansur and M. A. Aziz that the flexural toughness of the jute fiber-reinforced cement composite could be improved 
significantly by using jute fibers [128]. Liu et al. evaluated the effects of different fiber surface modifications, $2 \% \mathrm{NaOH}, 2$ $+5 \% \mathrm{NaOH}$ and coupling agent, on jute/PBS bio-composites [129]. The experiment results showed that surface modifications significantly increased the tensile strength and flexural strength (Figure. 13).

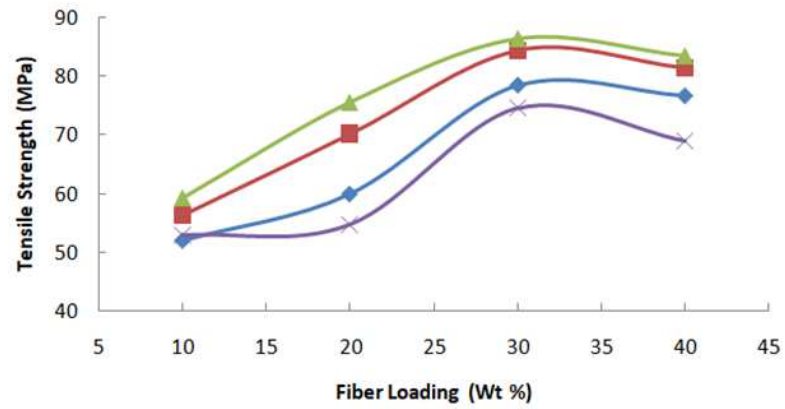

$\leadsto 0 \mathrm{Wt} \% \mathrm{Al}_{2} \mathrm{O}_{3} \rightarrow-5 \mathrm{Wt} \% \mathrm{Al}_{2} \mathrm{O}_{3} \longrightarrow-10 \mathrm{Wt} \% \mathrm{Al}_{2} \mathrm{O}_{3} \leftarrow 15 \mathrm{Wt} \% \mathrm{Al}_{2} \mathrm{O}_{3}$

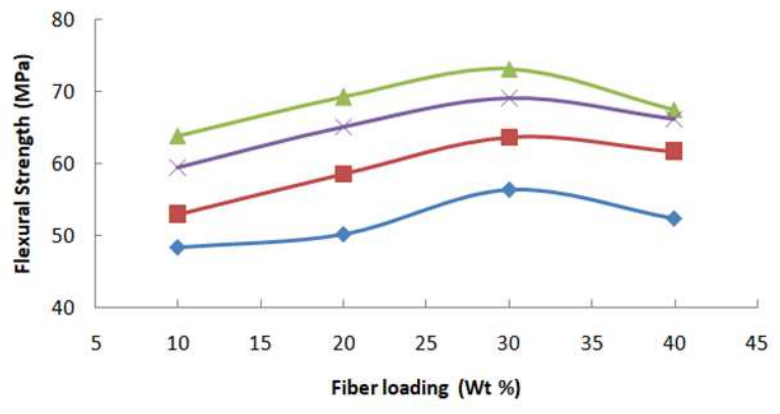

$\sim 0 \mathrm{Wt} \% \mathrm{Al}_{2} \mathrm{O}_{3}-5 \mathrm{Wt} \% \mathrm{Al}_{2} \mathrm{O}_{3} \rightarrow-10 \mathrm{Wt} \% \mathrm{Al}_{2} \mathrm{O}_{3} \leftarrow 15 \mathrm{Wt} \% \mathrm{Al}_{2} \mathrm{O}_{3}$

Figure 8: Effect of Fiber and Wt \% of Al2O3 Filler Loading on (Left) Tensile Strength, (Right) Flexural Strength of JF/Epoxy Composites (Adapted from [119]).
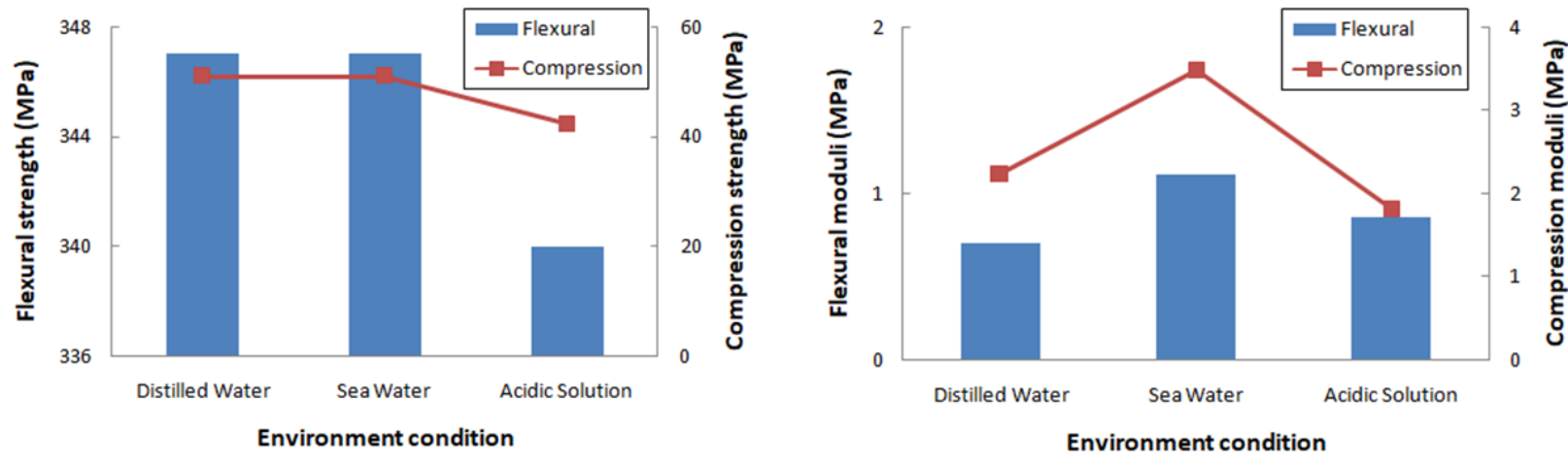

Figure 9: (Left) Flexural and Compression Strength, and (Right) Flexural and Compression Moduli Variation of Jute-Polyester Composites Exposed in Various Environments (Adapted from [121]).

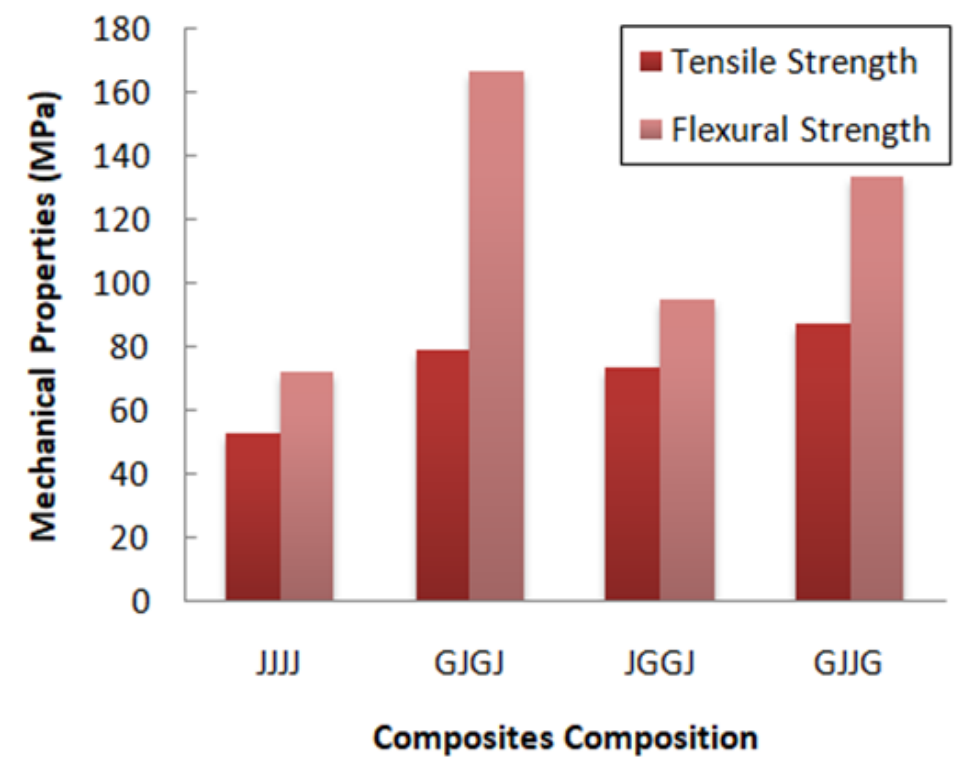

Figure 10: Mechanical Properties Variation in Different Stacking Sequence of Jute and Glass Fiber Hybrid Composites (Adapted from [122]). 
- Tensile Strength (MPa) $\quad$ Impact Strength (J)

229.54

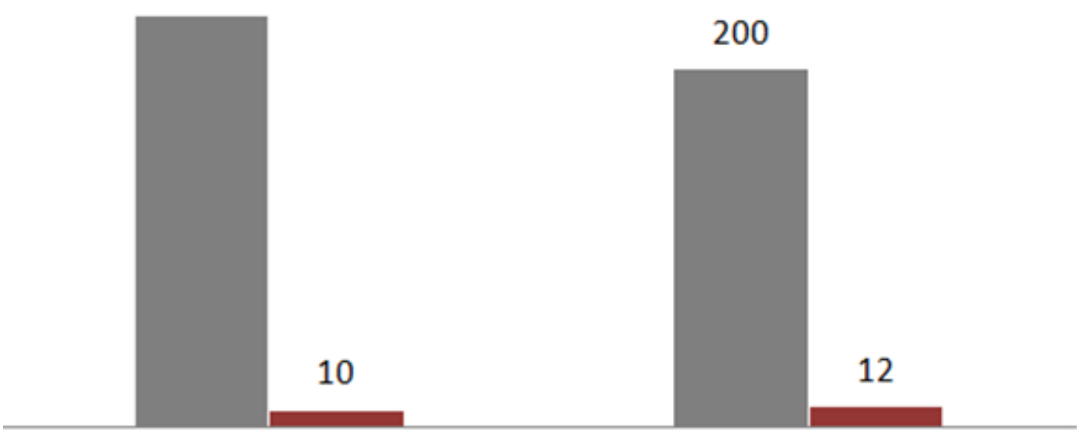

Glass Fiber+Jute Fiber Glass Fiber+Jute Fiber+Sisal Fiber

Figure 11: Tensile and Impact Strength Comparison of Different Composite Materials (Adapted from [124]).

From the above citations and discussions, it can be found that the values of the mechanical properties of jute fiber reinforced composites increased with increasing fiber loading up to a maximum or optimum value before falling back. However, it is generally true that the values of the young's modulus increased progressively with increasing fiber loading. Due to incompatible between matrix and fibers, improper manufacturing process, fiber degradation and others, some researchers found totally the opposite trend to the increase of composite strength with increasing fiber content.

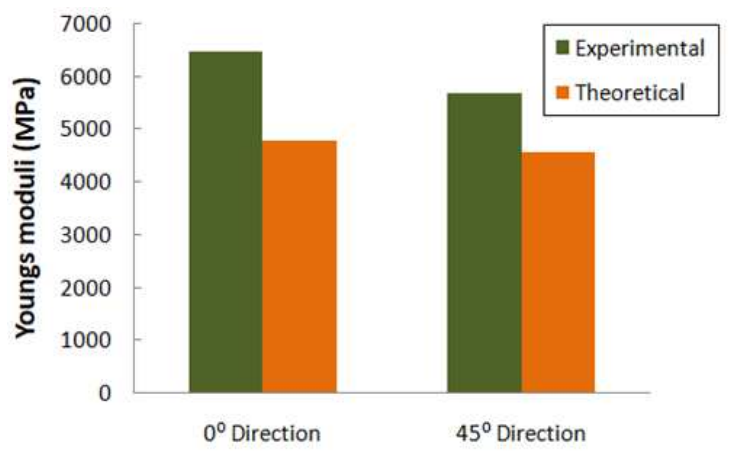

Fiber direction

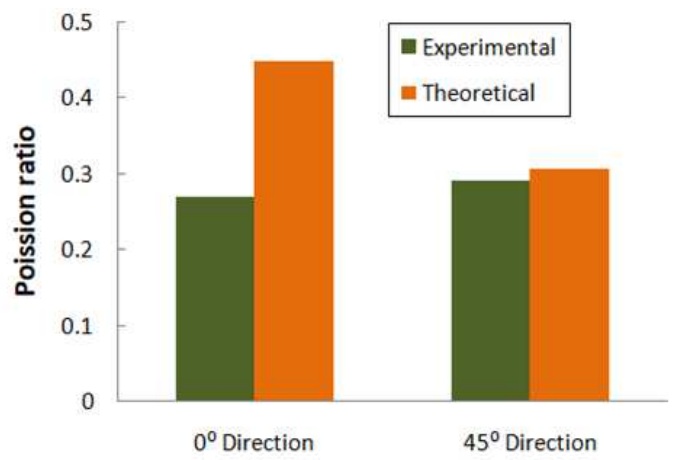

Fiber direction

Figure 12: Comparison of Experimental and Analytical (Left) Youngs Moduli, and (Right) Poission Ratio Variation with the Fiber Orientation in JF/Epoxy Composites (Adapted from [126]).
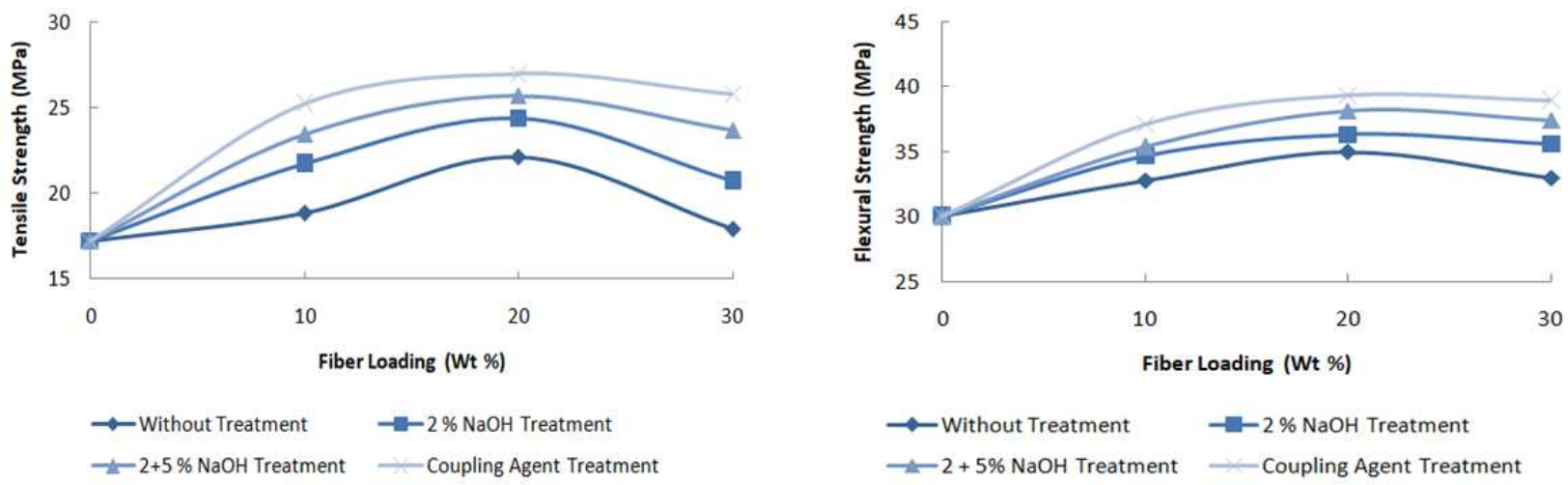

Figure 13: (Left) Tensile Strength and (Right) Flexural Strength Variation of NaOH Treated JF/PBS BioComposites (Adapted from [129]). 


\section{CONCLUSIONS AND FUTURE STUDY}

The use of jute fiber as reinforcement in polymer composite is expanding widely because of its advantageous and significant characteristics compared with other natural fibers. This article reviewed the chemical treatment, matrix selection, fabrication process of jute fiber-reinforced composites and its mechanical characteristics as well. It is noteworthy that the continuous improvements and a general guideline of the total manufacturing process is needed to ensure its development and new applications. Chemical treatment processes, such asbenzoylation treatment, peroxide treatment, isocyanate treatment, stearic acid treatment, permanganate treatment, triazine treatment, fungal treatment etc. that had been applied on other natural fiber surfaces can be applied on the jute fiber surface to investigate their effects. Another comparative study is recommended in the composite fabrication process. Jute fiber with the same matrix and similar chemically treated composite can be fabricated in a number of processes. The outcome can be compared to find out the most efficient composite manufacturing process for jute fiber-reinforced composite. A general guideline for the mass production of jute fiber reinforced polymer composite is needed so that industries can easily follow those steps to produce high-quality composites efficiently. It can be concluded that a lot of development and investigation is necessary to make jute fiber as a better reinforcement.

\section{REFERENCES}

1. May-Pat, A., Valadez-González, A., \& Herrera-Franco, P. J. (2013). Effect of fiber surface treatments on the essential work of fracture of HDPE-continuous henequen fiber-reinforced composites. Polymer Testing, 32(6), 1114-1122.

2. Handbook-Volume AM. (2001). 21-Composites, American Society of Metals. International Handbook Committee.

3. Verma, B. B. (2009). Continuous jute fibre reinforced laminated paper composite and reinforcement-fibre free paper laminate. Bulletin of Materials Science, 32(6), 589-595.

4. Chandramohan, D., \& Marimuthu, K. (2011). Tensile and hardness tests on natural fiber reinforced polymer composite material. Int. J. Adv. Eng. Sci. Technol, 6(1), 97-104.

5. Thakur, V. K., \& Thakur, M. K. (2014). Processing and characterization of natural cellulose fibers/thermoset polymer composites. Carbohydrate polymers, 109, 102-117.

6. Ali, M., Liu, A., Sou, H., \& Chouw, N. (2012). Mechanical and dynamic properties of coconut fibre reinforced concrete. Construction and Building Materials, 30, 814-825.

7. Kumar, R., Singh, T., \& Singh, H. (2015). Solid waste-based hybrid natural fiber polymeric composites. Journal of Reinforced Plastics and Composites, 34(23), 1979-1985.

8. Gassan, J., \& Bledzki, A. K. (1999). Alkali treatment of jute fibers: relationship between structure and mechanical properties. Journal of Applied Polymer Science, 71(4), 623-629.

9. Ray, D., Sarkar, B. K., Rana, A. K., \& Bose, N. R. (2001). Effect of alkali treated jute fibres on composite properties. Bulletin of materials science, 24(2), 129-135.

10. Mohanty, A. K., Khan, M. A., Sahoo, S., \& Hinrichsen, G. (2000). Effect of chemical modification on the performance of biodegradable jute yarn-Biopol® composites. Journal of Materials Science, 35(10), 2589-2595.

11. Karmaker, A. C., \& Youngquist, J. A. (1996). Injection molding of polypropylene reinforced with short jute fibers. Journal of Applied Polymer Science, 62(8), 1147-1151. 
12. Rana, A. K., Mitra, B. C., \& Banerjee, A. N. (1999). Short jute fiber-reinforced polypropylene composites: Dynamic mechanical study. Journal of Applied Polymer Science, 71(4), 531-539.

13. Corrales, F., Vilaseca, F., Llop, M., Girones, J., Mendez, J. A., \& Mutje, P. (2007). Chemical modification of jute fibers for the production of green-composites. Journal of Hazardous Materials, 144(3), 730-735.

14. Mir, A., Zitoune, R., Collombet, F., \& Bezzazi, B. (2010).Study of mechanical and thermomechanical properties of jutelepoxy composite laminate. Journal of Reinforced Plastics and Composites, 29(11), 1669-1680.

15. Hachemane, B., Zitoune, R., Bezzazi, B., \& Bouvet, C. (2013). Sandwich composites impact and indentation behaviour study. Composites Part B: Engineering, 51, 1-10.

16. George, M., Chae, M., \& Bressler, D. C. (2016). Composite materials with bastfibres: Structural, technical, and environmental properties. Progress in materials Science, 83, 1-23.

17. Van de Velde, K., \& Kiekens, P. (2001). Thermoplastic polymers: overview of several properties and their consequences in flax fibre reinforced composites. Polymer testing, 20(8), 885-893.

18. Tripathy, S. S., Di Landro, L., Fontanelli, D., Marchetti, A., \& Levita, G. (2000). Mechanical properties of jute fibers and interface strength with an epoxy resin. Journal of applied polymer science, 75(13), 1585-1596.

19. Stamman A.J. (1964).In Wood and Cellulose Science. New York: Ronald Press..

20. Tarkow H. \& Turner H. D. (1958).The swelling pressure of wood.Forest Products Journal.8, 193-197.

21. Lee, B. H., Kim, H. J., \& Yu, W. R. (2009). Fabrication of long and discontinuous natural fiber reinforced polypropylene biocomposites and their mechanical properties. Fibers and Polymers, 10(1), 83-90.

22. Li, X., Panigrahi, S., \& Tabil, L. G. (2009). A study on flax fiber-reinforced polyethylene biocomposites. Applied Engineering in Agriculture, 25(4), 525-531.

23. Yan, L., Chouw, N., \& Jayaraman, K. (2014). Flax fibre and its composites-A review. Composites Part B: Engineering, 56, 296-317.

24. LópezManchado, M. A., Arroyo, M., Biagiotti, J., \& Kenny, J. M. (2003). Enhancement of mechanical properties and interfacial adhesion of PP/EPDM/flax fiber composites using maleic anhydride as a compatibilizer. Journal of Applied Polymer Science, 90(8), 2170-2178.

25. Santos, E. F., Mauler, R. S., \& Nachtigall, S. M. (2009). Effectiveness of maleated-and silanized-PP for coir fiber-filled composites. Journal of Reinforced Plastics and composites, 28(17), 2119-2129.

26. Virk A. S., Hall W.,\& Summerscales J. (2009).Tensile properties of jute fibres.Materials Science and Technology.25,12891295.

27. Johnson D.J. (1979).High-Temperature stable and high-performance fibres. Applied Fibre.

28. Shenouda S. G. (1979).The structure of cotton cellulose. London, Academic Press.

29. Zeronian S. H. (1985).Intra-crystalline swelling of cellulose.New York. E. Horwood/Halsted Press.

30. Mwaikambo, L. Y., \& Ansell, M. P. (2002). Chemical modification of hemp, sisal, jute, and kapok fibers by alkalization. Journal of applied polymer science, 84(12), 2222-2234.

31. Ray, D., Sarkar, B. K., Rana, A. K., \& Bose, N. R. (2001). Effect of alkali treated jute fibres on composite properties. Bulletin of materials science, 24(2), 129-135.. 
32. Al Azad, S., Deb, H., Rumi, T. M., \& Ahmed, M. R. (2017). Effect of Alkalization on Fabrication and Mechanical Properties of Jute Fiber Reinforced Jute-Polyester Resin Hybrid Epoxy Composite.

33. Sadaq, S. I., \& Mohammed, S. (2013). Experimental study and the effect of alkali treatment with time on jute polyester composites. International Journal of Engineering Research, 2(2), 23-28.

34. Amantes, B. D. P., Melo, R. P. D., Neto, R. P. C., \& Marques, M. D. F. V. (2017). Chemical treatment and modification of jute fiber surface. Chemistry \& Chemical Technology, 3 (11), 2017, 11(3), 333-343.

35. Dilfi KF, A., Balan, A., Bin, H., Xian, G., \& Thomas, S. (2018). Effect of surface modification of jute fiber on the mechanical properties and durability of jute fiber-reinforced epoxy composites. Polymer Composites, 39(S4), E2519-E2528.

36. Atkins E. (1979). Polysaccharides: Biomolecular shape and structure. New York. Academic Press.

37. Mishra, S., Misra, M., Tripathy, S. S., Nayak, S. K., \&Mohanty, A. K. (2001). Graft copolymerization of acrylonitrile on chemically modified sisal fibers. Macromolecular materials and engineering, 286(2), 107-113.

38. Valadez-Gonzalez, A., Cervantes-UC, J. M., Olayo, R., \& Herrera-Franco, P. J. (1999). Chemical modification of henequen fibers with an organosilane coupling agent. Composites Part B: Engineering, 30(3), 321-331.

39. Joseph, K., Thomas, S., \&Pavithran, C. (1996). Effect of chemical treatment on the tensile properties of short sisal fibrereinforced polyethylene composites. Polymer, 37(23), 5139-5149.

40. Sarkar, B. K., \& Ray, D. (2004). Effect of the defect concentration on the impact fatigue endurance of untreated and alkali treated jute-vinylester composites under normal and liquid nitrogen atmosphere. Composites Science and Technology, 64(1314), 2213-2219.

41. Jacob, M., Thomas, S., \&Varughese, K. T. (2004). Mechanical properties of sisal/oil palm hybrid fiber reinforced natural rubber composites. Composites science and Technology, 64(7-8), 955-965.

42. Mukherjee, A., Ganguly, P. K., \& Sur, D. (1993). Structural mechanics of jute: the effects of hemicellulose or lignin removal. Journal of the Textile Institute, 84(3), 348-353.

43. HearleJ. W. (1963).Structure, properties, and uses.Fibre structure.621-640.

44. Sreekala, M. S., Kumaran, M. G., Joseph, S., Jacob, M., \& Thomas, S. (2000). Oil palm fibre reinforced phenol formaldehyde composites: influence of fibre surface modifications on the mechanical performance. Applied Composite Materials, 7(5-6), 295-329.

45. Wang, B., Panigrahi, S., Tabil, L., \&Crerar, W. (2007). Pre-treatment of flax fibers for use in rotationally molded biocomposites. Journal of reinforced plastics and composites, 26(5), 447-463.

46. George, J., Sreekala, M. S., \& Thomas, S. (2001). A review on interface modification and characterization of natural fiber reinforced plastic composites. Polymer Engineering \& Science, 41(9), 1471-1485.

47. Agrawal, R., Saxena, N. S., Sharma, K. B., Thomas, S., \&Sreekala, M. S. (2000). Activation energy and crystallization kinetics of untreated and treated oil palm fibre reinforced phenol formaldehyde composites. Materials Science and Engineering: A, 277(1-2), 77-82.

48. Seki, Y. (2009). Innovative multifunctional siloxane treatment of jute fiber surface and its effect on the mechanical properties of jute/thermoset composites. Materials Science and Engineering: A, 508(1-2), 247-252.

49. Amantes, B. D. P., Melo, R. P. D., Neto, R. P. C., \& Marques, M. D. F. V. (2017). Chemical treatment and modification of jute fiber surface. Chemistry \& Chemical Technology, 3 (11), 2017, 11(3), 333-343.[50Rong, M. Z., Zhang, M. Q., Liu, Y., Yang, 
G. C., \& Zeng, H. M. (2001). The effect of fiber treatment on the mechanical properties of unidirectional sisal-reinforced epoxy composites. Composites Science and technology, 61(10), 1437-1447.

50. Hill, C. A., Khalil, H. A., \& Hale, M. D. (1998). A study of the potential of acetylation to improve the properties of plant fibres. Industrial Crops and Products, 8(1), 53-63.

51. Tserki, V., Zafeiropoulos, N. E., Simon, F., \& Panayiotou, C. (2005). A study of the effect of acetylation and propionylation surface treatments on natural fibres. Composites Part A: applied science and manufacturing, 36(8), 1110-1118.

52. Mwaikambo, L. Y., \& Ansell, M. P. (1999). The effect of chemical treatment on the properties of hemp, sisal, jute and kapok for composite reinforcement. Die angewandtemakromolekulareChemie, 272(1), 108-116.

53. Rowell R. M., Young R. A., and Rowell J. (1996).Paper and composites from agro-based resources. Taylor \& Francis Ltd., CRC Press.[55]. Sahoo, P. K., Samantaray, H. S., \&Samal, R. K. (1986). Graft copolymerization with new class of acidic peroxo salts as initiators. I. Grafting of acrylamide onto cotton-cellulose using potassium monopersulfate, catalyzed by co (II). Journal of applied polymer science, 32(7), 5693-5703.

54. Bledzki, A. K., \&Gassan, J. (1999). Composites reinforced with cellulose based fibres. Progress in polymer science, 24(2), 221-274.

55. Jähn, A., Schröder, M. W., Füting, M., Schenzel, K., \&Diepenbrock, W. (2002). Characterization of alkali treated flax fibres by means of FT Raman spectroscopy and environmental scanning electron microscopy. SpectrochimicaActa Part A: Molecular and Biomolecular Spectroscopy, 58(10), 2271-2279.

56. Bogoeva-Gaceva, G., Avella, M., Malinconico, M., Buzarovska, A., Grozdanov, A., Gentile, G., \&Errico, M. E. (2007). Natural fiber eco-composites. Polymer composites, 28(1), 98-107.

57. Zahran, M. K., \&Rehan, M. F. (2006). Grafting of acrylic acid onto flax fibers using Mn (IV)-citric acid redox system. Journal of applied polymer science, 102(3), 3028-3036.

58. Mohanty, S., Nayak, S. K., Verma, S. K., \&Tripathy, S. S. (2004). Effect of MAPP as a coupling agent on the performance of jute-PP composites. Journal of reinforced plastics and composites, 23(6), 625-637.

59. Patel, V. A., \&Parsania, P. H. (2010). Performance Evaluation of Alkali and Acrylic Acid Treated-Untreated Jute Composites of Mixed Epoxy—Phenolic Resins. Journal of reinforced plastics and composites, 29(5), 725-730.

60. Keener, T. J., Stuart, R. K., \& Brown, T. K. (2004). Maleated coupling agents for natural fibre composites. Composites Part A: applied science and manufacturing, 35(3), 357-362.

61. Van de Velde, K., \&Kiekens, P. (2003).Effect of material and process parameters on the mechanical properties of unidirectional and multidirectional flax/polypropylene composites. Composite structures, 62(3-4), 443-448.

62. Cantero, G., Arbelaiz, A., Llano-Ponte, R., \& Mondragon, I. (2003). Effects of fibre treatment on wettability and mechanical behaviour of flax/polypropylene composites. Composites science and technology, 63(9), 1247-1254.

63. Joseph, K., TolêdoFilho, R. D., James, B., Thomas, S., \&Carvalho, L. H. D. (1999). A review on sisal fiber reinforced polymer composites. RevistaBrasileira de EngenhariaAgrícola e Ambiental, 3(3), 367-379.

64. Gassan, J., \&Bledzki, A. K. (1997). The influence of fiber-surface treatment on the mechanical properties of jutepolypropylene composites. Composites Part A: Applied Science and Manufacturing, 28(12), 1001-1005.

65. Van den Oever, M., \&Peijs, T. (1998).Continuous-glass-fibre-reinforced polypropylene composites II. Influence of maleicanhydride modified polypropylene on fatigue behaviour. Composites Part A: Applied Science and Manufacturing, 29(3), 227239. 
66. Joseph, P. V., Joseph, K., Thomas, S., Pillai, C. K. S., Prasad, V. S., Groeninckx, G., \&Sarkissova, M. (2003). The thermal and crystallisation studies of short sisal fibre reinforced polypropylene composites. Composites Part A: Applied Science and Manufacturing, 34(3), 253-266.

67. Mishra, S., Mohanty, A. K., Drzal, L. T., Misra, M., Parija, S., Nayak, S. K., \&Tripathy, S. S. (2003). Studies on mechanical performance of biofibre/glass reinforced polyester hybrid composites. Composites Science and Technology, 63(10), 13771385.

68. Keener, T. J., Stuart, R. K., \& Brown, T. K. (2004). Maleated coupling agents for natural fibre composites. Composites Part A: applied science and manufacturing, 35(3), 357-362.

69. Corrales, F., Vilaseca, F., Llop, M., Girones, J., Mendez, J. A., \&Mutje, P. (2007). Chemical modification of jute fibers for the production of green-composites. Journal of Hazardous Materials, 144(3), 730-735.

70. Kumar, R. A. S. H. M. I. "Indian jute industry and its future." International Journal of Business and General Management 6.4 (2017): 21-32.

71. Militký, J., \&Jabbar, A. (2015). Comparative evaluation of fiber treatments on the creep behavior of jute/green epoxy composites. Composites Part B: Engineering, 80, 361-368.

72. Štěpánková M., Wiener J., and Dembický J. (2010).Impact of laser thermal stress on cotton fabric.Fibres and Textiles in Eastern Europe.

73. Adekunle, K., Åkesson, D., \&Skrifvars, M. (2010). Biobased composites prepared by compression molding with a novel thermoset resin from soybean oil and a natural-fiber reinforcement. Journal of applied polymer science, 116(3), 1759-1765.

74. Kabir, M. M., Wang, H., Lau, K. T., \& Cardona, F. (2012). Chemical treatments on plant-based natural fibre reinforced polymer composites: An overview. Composites Part B: Engineering, 43(7), 2883-2892.

75. Jalil, Mohammad Abdul, et al. "Analysis of physio-mechanical properties of jute-PALF Union fabrics." International Journal of Mechanical Engineering 4.3 (2015): 23-28.

76. Al Azad, S., Deb, H., Rumi, T. M., \& Ahmed, M. R. (2017). Effect of Alkalization on Fabrication and Mechanical Properties of Jute Fiber Reinforced Jute-Polyester Resin Hybrid Epoxy Composite.

77. Saha, A. K., Das, S., Bhatta, D., \&Mitra, B. C. (1999). Study of jute fiber reinforced polyester composites by dynamic mechanical analysis. Journal of applied polymer science, 71(9), 1505-1513.

78. Reddy, T. BALARAMI."Mechanical performance of green coconut fiber/HDPE composites by using flexural strength." International Journal of Mechanical Engineering (IJME), 3 (1), 5366 (2014).

79. Sanjay, M. A., \&Yogesha, B. (2016). Studies on mechanical properties of jute/E-glass fiber reinforced epoxy hybrid composites. Journal of Minerals and materials characterization and engineering, 4(1), 15-25.

80. Chaudhary, V., Bajpai, P. K., \&Maheshwari, S. (2018). Studies on mechanical and morphological characterization of developed jute/hemp/flax reinforced hybrid composites for structural applications. Journal of natural fibers, 15(1), 80-97.

81. Musalaiah, G., et al. "Compressive and Flexural Strength Improvement of Jute Fibre Reinforced Polymer Composite." International Journal of Mechanical and Production Engineering Research and Development (IJMPERD) 7.4 (2017): 235-240.

82. Devireddy, S. B. R., \& Biswas, S. (2017). Physical and mechanical behavior of unidirectional banana/jute fiber reinforced epoxy based hybrid composites. Polymer Composites, 38(7), 1396-1403. 
83. Braga Braga, R. A., \&Magalhaes Jr, P. A. A. (2015). Analysis of the mechanical and thermal properties of jute and glass fiber as reinforcement epoxy hybrid composites. Materials science and engineering: C, 56, 269-273.

84. Zafar, M. T., Maiti, S. N., \& Ghosh, A. K. (2016). Effect of surface treatments of jute fibers on the microstructural and mechanical responses of poly (lactic acid)/jute fiber biocomposites. RSC advances, 6(77), 73373-73382.

85. Parsania, P. H., Sanariya, M. R., Godhani, D. R., \&Baluja, S. (1998). Synthesis and characterization of epoxy resins based on 1, 1'-bis (4-hydroxyphenyl) cyclohexane and 1, 1'-bis) 3-methyl-4-hydroxyphenyl) cyclohexane. Journal of Polymer Materials(Netherlands), 15(1), 45-49.

86. Parsania, P. H., \&Sanariya, M. R. (2000). Synthesis of new bisphenol-formaldehyde and bisphenol-formaldehyde-epoxy resins. Journal of Polymer Materials(Netherlands), 17(3), 261-266.

87. Patel, V. A., Vasoya, P. J., \&Parsania, P. H. (2007). Preparation, mechanical, electrical and water absorption behavior of jute composites of bisphenol-C based mixed epoxy-phenolic resins. Journal of Polymer Materials, 24(3), 255-261.

88. Li, Y., Ma, H., Shen, Y., Li, Q., \& Zheng, Z. (2015). Effects of resin inside fiber lumen on the mechanical properties of sisal fiber reinforced composites. Composites Science and Technology, 108, 32-40.

89. Bledzki, A. K., Mamun, A. A., \&Faruk, O. (2007). Abaca fibre reinforced PP composites and comparison with jute and flax fibre PP composites. eXPRESS polymer letters, 1(11), 755-762.

90. Rahman, M. R., Huque, M. M., Islam, M. N., \& Hasan, M. (2008). Improvement of physico-mechanical properties of jute fiber reinforced polypropylene composites by post-treatment. Composites Part A: Applied Science and Manufacturing, 39(11), 1739-1747.

91. Rezaur Rahman, M., Hasan, M., MonimulHuque, M., \&Nazrul Islam, M. (2010).Physico-mechanical properties of jute fiber reinforced polypropylene composites. Journal of Reinforced Plastics and Composites, 29(3), 445-455.

92. Yang, Y., Ota, T., Morii, T., \& Hamada, H. (2011). Mechanical property and hydrothermal aging of injection molded jute/polypropylene composites. Journal of Materials Science, 46(8), 2678-2684.

93. Holbery, J., \& Houston, D. (2006). Natural-fiber-reinforced polymer composites in automotive applications. Jom, 58(11), 8086.

94. Summerscales, J., Virk, A., \& Hall, W. (2013). A review of bastfibres and their composites: Part 3-Modelling. Composites Part A: Applied Science and Manufacturing, 44, 132-139.

95. Dos Santos, P. A., Giriolli, J. C., Amarasekera, J., \&Moraes, G. (2008, September). Natural fibers plastic composites for automotive applications.In 8th Annual automotive composites conference and exhibition (ACCE 2008). Troy, MI: SPE Automotive \& Composites Division (pp. 492-500).

96. Chand, N., \&Dwivedi, U. K. (2006). Effect of coupling agent on abrasive wear behaviour of chopped jute fibre-reinforced polypropylene composites. Wear, 261(10), 1057-1063.

97. Karmaker, A. C. (1997). Effect of water absorption on dimensional stability and impact energy of jute fibre reinforced polypropylene. Journal of materials science letters, 16(6), 462-464.

98. Brodowsky, H., \&Mäder, E. (2007). Jute fibre/polypropylene composites II.Thermal, hydrothermal and dynamic mechanical behaviour. Composites Science and Technology, 67(13), 2707-2714.

99. Karmaker, A. C., \& Schneider, J. P. (1996). Mechanical performance of short jute fibre reinforced polypropylene. Journal of materials science letters, 15(3), 201-202. 
100. Akil, H. M., Cheng, L. W., Ishak, Z. M., Bakar, A. A., \& Rahman, M. A. (2009). Water absorption study on pultruded jute fibre reinforced unsaturated polyester composites. Composites Science and Technology, 69(11-12), 1942-1948.

101. Sinha, E., \& Rout, S. K. (2009). Influence of fibre-surface treatment on structural, thermal and mechanical properties of jute fibre and its composite. Bulletin of materials science, 32(1), 65.

102. Clark, R. A., \& Ansell, M. P. (1986). Jute and glass fibre hybrid laminates. Journal of Materials Science, 21(1), $269-276$.

103. Jawaid, M., Khalil, H. A., Bakar, A. A., \&Khanam, P. N. (2011). Chemical resistance, void content and tensile properties of oil palm/jute fibre reinforced polymer hybrid composites. Materials \& Design, 32(2), 1014-1019.

104. Jawaid, M., Khalil, H. A., Hassan, A., Dungani, R., \&Hadiyane, A. (2013).Effect of jute fibre loading on tensile and dynamic mechanical properties of oil palm epoxy composites. Composites Part B: Engineering, 45(1), 619-624.

105. Ramnath, B. V., Kokan, S. J., Raja, R. N., Sathyanarayanan, R., Elanchezhian, C., Prasad, A. R., \&Manickavasagam, V. M. (2013). Evaluation of mechanical properties of abaca-jute-glass fibre reinforced epoxy composite. Materials \& Design, 51, 357-366

106. Singh, B., Gupta, M., \&Verma, A. (2000).The durability of jute fibre-reinforced phenolic composites. Composites Science and Technology, 60(4), 581-589.

107. Faruk, O., Bledzki, A. K., Fink, H. P., \&Sain, M. (2014). Progress report on natural fiber reinforced composites. Macromolecular Materials and Engineering, 299(1), 9-26.

108. Gopinath, A., Kumar, M. S., \&Elayaperumal, A. (2014). Experimental investigations on mechanical properties of jute fiber reinforced composites with polyester and epoxy resin matrices. Procedia Engineering, 97(10.1016).

109. Liu, L., Yu, J., Cheng, L., \& Yang, X. (2009). Biodegradability of poly (butylene succinate)(PBS) composite reinforced with jute fibre. Polymer Degradation and Stability, 94(1), 90-94.

110. Tripathi, P., Gupta, V. K., Dixit, A., Mishra, R. K., \& Sharma, S. (2018). Development and characterization of low cost jute, bagasse and glass fiber reinforced advanced hybrid epoxy composites. AIMS Materials Science, 5(2), 320-37.

111. Kaushik, P., Jaivir, J., \& Mittal, K. (2017). Analysis of mechanical properties of jute fiber strengthened epoxy/polyester composites. Engineering Solid Mechanics, 5(2), 103-112.

112. Pickering, K. L., Efendy, M. A., \& Le, T. M. (2016).A review of recent developments in natural fibre composites and their mechanical performance. Composites Part A: Applied Science and Manufacturing, 83, 98-112.

113. Shah, D. U., Porter, D., \&Vollrath, F. (2014). Can silk become an effective reinforcing fibre? A property comparison with flax and glass reinforced composites. Composites Science and Technology, 101, 173-183.

114. Charlet, K., Baley, C., Morvan, C., Jernot, J. P., Gomina, M., \&Bréard, J. (2007).Characteristics of Hermès flax fibres as a function of their location in the stem and properties of the derived unidirectional composites. Composites Part A: Applied Science and Manufacturing, 38(8), 1912-1921.

115. Le, T. M., \& Pickering, K. L. (2015).The potential of harakeke fibre as reinforcement in polymer matrix composites including modelling of long harakeke fibre composite strength. Composites Part A: Applied Science and Manufacturing, 76, 44-53.

116. Beg, M. D. H. (2007). The improvement of interfacial bonding, weathering and recycling of wood fibre reinforced polypropylene composites (Doctoral dissertation, The University of Waikato).

117. Beckermann, G. (2007). Performance of hemp-fibre reinforced polypropylene composite materials (Doctoral dissertation, The University of Waikato). 
118. Madsen, B., Thygesen, A., \&Lilholt, H. (2009).Plant fibre composites-porosity and stiffness. Composites Science and Technology, 69(7-8), 1057-1069.

119. Berhanu, T., Kumar, P., \& Singh, I. (2014, December). Mechanical behaviour of jute fibre reinforced polypropylene composites. In 5th International \& 25th All India Manufacturing Technology, Design and Research Conference (AIMTDR 2014) December 12th-14th.

120. Lee, B. H., Kim, H. J., \& Yu, W. R. (2009). Fabrication of long and discontinuous natural fiber reinforced polypropylene biocomposites and their mechanical properties. Fibers and Polymers, 10(1), 83-90.

121. Swain, P. T. R., \& Biswas, S. (2014). Physical and mechanical behavior of Al2O3 filled jute fiber reinforced epoxy composites. International Journal of Current Engineering and Technology, 2, 67-71.

122. Dash, D., Samanta, S., Gautam, S. S., \&Murlidhar, M. (2013). Mechanical characterizations of natural fiber reinforced composite materials. Advanced Materials Manufacturing \& Characterization, 3(1), 275-279.

123. Zamri, M. H., Akil, H. M., Bakar, A. A., Ishak, Z. A. M., \& Cheng, L. W. (2012). Effect of water absorption on pultruded jute/glass fiber-reinforced unsaturated polyester hybrid composites. Journal of composite materials, 46(1), 51-61.

124. Gujjala, R., Ojha, S., Acharya, S. K., \& Pal, S. K. (2014). Mechanical properties of woven jute-glass hybrid-reinforced epoxy composite. Journal of Composite Materials, 48(28), 3445-3455.

125. Pujari, S., Ramakrishna, A., \& Kumar, M. S. (2014). Comparison of jute and banana fiber composites: A review. International Journal of Current Engineering and Technology, 2(2), 121-126.

126. Ramesh, M., Palanikumar, K., \& Reddy, K. H. (2013). Mechanical property evaluation of sisal-jute-glass fiber reinforced polyester composites. Composites Part B: Engineering, 48, 1-9.

127. Arao, Y., Fujiura, T., Itani, S., \& Tanaka, T. (2015).Strength improvement in injection-molded jute-fiber-reinforced polylactide green-composites. Composites Part B: Engineering, 68, 200-206.

128. Abdellaoui, H., Bensalah, H., Echaabi, J., Bouhfid, R., \&Qaiss, A. (2015). Fabrication, characterization and modelling of laminated composites based on woven jute fibres reinforced epoxy resin. Materials \& Design, 68, 104-113.

129. Bledzki, A. K., Mamun, A. A., Lucka-Gabor, M., \&Gutowski, V. S. (2008).The effects of acetylation on properties of flax fibre and its polypropylene composites. Express Polymer Letters, 2(6), 413-422.

130. Mansur, M. A., \& Aziz, M. A. (1982). A study of jute fibre reinforced cement composites. International Journal of Cement Composites and Lightweight Concrete, 4(2), 75-82.

131. Liu, L., Yu, J., Cheng, L., \& Qu, W. (2009). Mechanical properties of poly (butylene succinate) (PBS) biocomposites reinforced with surface modified jute fibre. Composites Part A: Applied Science and Manufacturing, 40(5), 669-674. 